\title{
Prediction of lisinopril pediatric dose from the reference adult dose by employing a physiologically based pharmacokinetic model
}

Memoona Rashid', Muhammad Sarfraz ${ }^{2,3}$, Mosab Arafat ${ }^{3}$, Amjad Hussain ${ }^{1}$, Nasir Abbas', Muhammad Waqas Sadiq ${ }^{4}$, Muhammad Fawad Rasool ${ }^{5}$ and Nadeem Irfan Bukhari ${ }^{{ }^{*}}$ (D)

\begin{abstract}
Background: This study aimed to assess the pediatric lisinopril doses using an adult physiological based pharmacokinetic (PBPK) model. As the empirical rules of dose calculation cannot calculate gender-specific pediatric doses and ignores the age-related physiological differences.

Methods: A PBPK model of lisinopril for the healthy adult population was developed for oral (fed and fasting) and IV administration using PK-Sim MoBl ${ }^{\circledR}$ and was scaled down to a virtual pediatric population for prediction of lisinopril doses in neonates to infants, infants to toddler, children at pre-school age, children at school age and the adolescents. The pharmacokinetic parameters were predicted for the above groups at decremental doses of $20 \mathrm{mg}$, $10 \mathrm{mg}, 5 \mathrm{mg}, 2.5 \mathrm{mg}$, and $1.5 \mathrm{mg}$ in order to accomplish doses producing the pharmacokinetic parameters, similar (or comparable) to that of the adult population. The above simulated pediatric doses were compared to the doses computed using the conventional four methods, such as Young's rule, Clark's rule, and weight-based and body surface area-based equations and the dose reported in different studies.
\end{abstract}

Results: Though the doses predicted for all subpopulations of children were comparable to those calculated by Young's rule, yet the conventional methods overestimated the pediatric doses when compared to the respective PBPK-predicted doses. The findings of previous real time pharmacokinetic studies in pediatric patients supported the present simulated dose.

Conclusion: Thus, PBPK seems to have predictability potential for pediatric dose since it takes into consideration the physiological changes related to age and gender.

Keywords: Lisinopril, PBPK, Pediatric, PK-Sim MoBI ${ }^{\circledR}$, Area under the curve

\footnotetext{
* Correspondence: nadeem irfan@hotmail.com

'Punjab University College of Pharmacy, University of the Punjab, Lahore,

Pakistan

Full list of author information is available at the end of the article
}

(c) The Author(s). 2020 Open Access This article is licensed under a Creative Commons Attribution 4.0 International License, which permits use, sharing, adaptation, distribution and reproduction in any medium or format, as long as you give appropriate credit to the original author(s) and the source, provide a link to the Creative Commons licence, and indicate if changes were made. The images or other third party material in this article are included in the article's Creative Commons licence, unless indicated otherwise in a credit line to the material. If material is not included in the article's Creative Commons licence and your intended use is not permitted by statutory regulation or exceeds the permitted use, you will need to obtain permission directly from the copyright holder. To view a copy of this licence, visit http://creativecommons.org/licenses/by/4.0/ The Creative Commons Public Domain Dedication waiver (http://creativecommons.org/publicdomain/zero/1.0/) applies to the data made available in this article, unless otherwise stated in a credit line to the data. 


\section{Background}

Administration of a right dose is a critical factor to obtain optimum systemic drug concentration and its therapeutic effect. Any deviation from the optimum systemic drug concentration may lead to toxic or subtherapeutic drug levels [1]. According to the guidelines of FDA, EMA and equivalent drug regulatory authorities, effective and safe dose and dose adjustments are needed in different clinical situations and for the other covariates, i.e., age, gender, obesity, pregnancy and disease states, i.e., renal disease [2] or hepatic disease [3].

The efficacy, safety and tolerability of different dosage forms of a drug are determined usually in adult population during phase I clinical trials [4]. Due to ethical, technical and regulatory restrictions, pharmacokinetic and clinical studies in the pediatric population are scarce [5]. Thus, pediatric dose is calculated from that of adult using the empirical formulae [6,7] based on the size, age, weight and body surface area (BSA) of pediatric patients. Nevertheless, the above conventional methods have certain limitations; the Young's rule (Eq. 1) ignores the varied sizes, weights and genetics of the individuals of the same age [8]. The Clark's rule (Eq. 2) considers a linear relationship, between dose and weight, which indeed is otherwise. Computation of BSA-based (Eq. 3) pediatric dose is considered relatively reliable among the other methods for dose calculation $[4,9,10]$.

$$
\begin{aligned}
& \text { Young's Rule }=\frac{\text { Age }}{(\text { Age }+12)} \\
& \text { Clark' s Rule }=\frac{\text { Weight }(\mathrm{lb})}{150} \times 100 \\
& \text { BSA }\left(\mathrm{m}^{2}\right)=\frac{\sqrt{\text { Height }(\mathrm{Cm}) \times \text { Weight }(\mathrm{Kg})}}{3600}
\end{aligned}
$$

The conventional methods are assumptions-based and ignore all the age-dependent physiological difference which can affect the pharmacokinetics and pharmacodynamics of a drug [11]. For instance, the absorption and metabolizing capacity, expression of enzymes in the liver, parameters relevant to distribution (such as protein binding), and excretion process (such as glomerular filtration) differ in children and adults [12, 13]. Furthermore, existence of the physiological differences among the children of different age groups [1] warrants more reliable and accurate options for dose computation in children.

The European Union and FDA have enforced and encouraged the need of drug development study of a new chemical entity for pediatrics use by employing PBPK model approach [14] for being a more advanced and sophisticated tool for the prediction of pharmacokinetic parameters in individuals of different age groups by considering the age-led physiological changes [1519]. However, the PBPK approach is not without limitations, one of these is lacking literature to develop an accurate PBPK model and high technical expertise are required for correct model development.

In the recent years, the prevalence of primary hypertension in the pediatric population has increased largely. Its occurrence is about 3 to $5 \%$ in the USA and can be higher in other populations such as nonHispanic blacks and Mexican Americans [20]. The model drug, lisinopril is being used for the treatment of hypertension in the pediatric population [21]. Limited dose-response and pharmacokinetic studies of lisinopril in pediatric populations had concluded varied pediatric doses [22-24]. Hence, there was a need for well-designed and established clinical studies of lisinopril in the pediatric population [25]. Lisinopril is an oral long-acting synthetic peptidyl dipeptidase inhibitor of angiotensin-converting enzyme (ACE) [26, 27], belongs to BCS III drugs, i.e., it has high water solubility and low permeability [28], and exhibits poor bioavailability (25\%) with 6-60\% inter-individual variability [29]. This inter-individual variability has been reported at all doses ranging from 5 to $50 \mathrm{mg}$ of the drug [27]. Nevertheless, lisinopril has simple pharmacokinetics, excreted by renal route [30], does not undergo metabolism [25] and has saturable binding to ACE but does not bind with any other binding protein [31]. This drug has proven safety and effectiveness in adults, and as stated earlier, it is being used in children for hypertension. There was a need for developing a model which could predict lisinopril concentrations in various pediatric age groups to help in developing standard treatment guidelines.

To demonstrate the applicability of PBPK modeling for prediction of pediatric dose, we developed a PBPK model for lisinopril in adult population to scale down its dose to different subgroups of the pediatric population, by graded decremental dose method. To our best knowledge, we used a novel PBPK method for the prediction of pediatric dose. Previously, dose calculation using PBPK model involved the assessment of pharmacokinetics based on the dose range reported already from a clinical study [14] or accomplishing pharmacokinetics based on the dose computed from conventional methods, i.e., BSA- or weight-based equations [32, 33].

\section{Methods}

Software tool

PK-Sim-MoBI ${ }^{\odot}$ (Version 5.4.3/3.4.3, Bayer Technology Services, Leverkusen, Germany; http://www.systemsbiology.com), was used for the development of PBPK model. The age-dependent anatomical and physiological parameters of humans and different species used in the 
experimental studies have been in-built in the database of the tool [34].

\section{Development of adult IV PBPK models of lisinopril}

A previously reported systematic approach [14, 35] was adopted for the development and validation of adult PBPK model of lisinopril (Fig. 1). For the development of PBPK model, all the population and drug specific parameters, including that of physicochemical and absorption, distribution metabolism and excretion
(ADME), shown in Table 1 and Table 2 were entered as inputs under the respective nodes of PK-Sim.

\section{Development of adult oral PBPK models of lisinopril}

The values of different model input parameters required for the development of PBPK models of lisinopril is given as:

- Age: A clinical study on lisinopril in adult population of age range 21 to 37 [42] was selected as reference. According to the reference clinical study, a mean virtual healthy adult individual of age 29

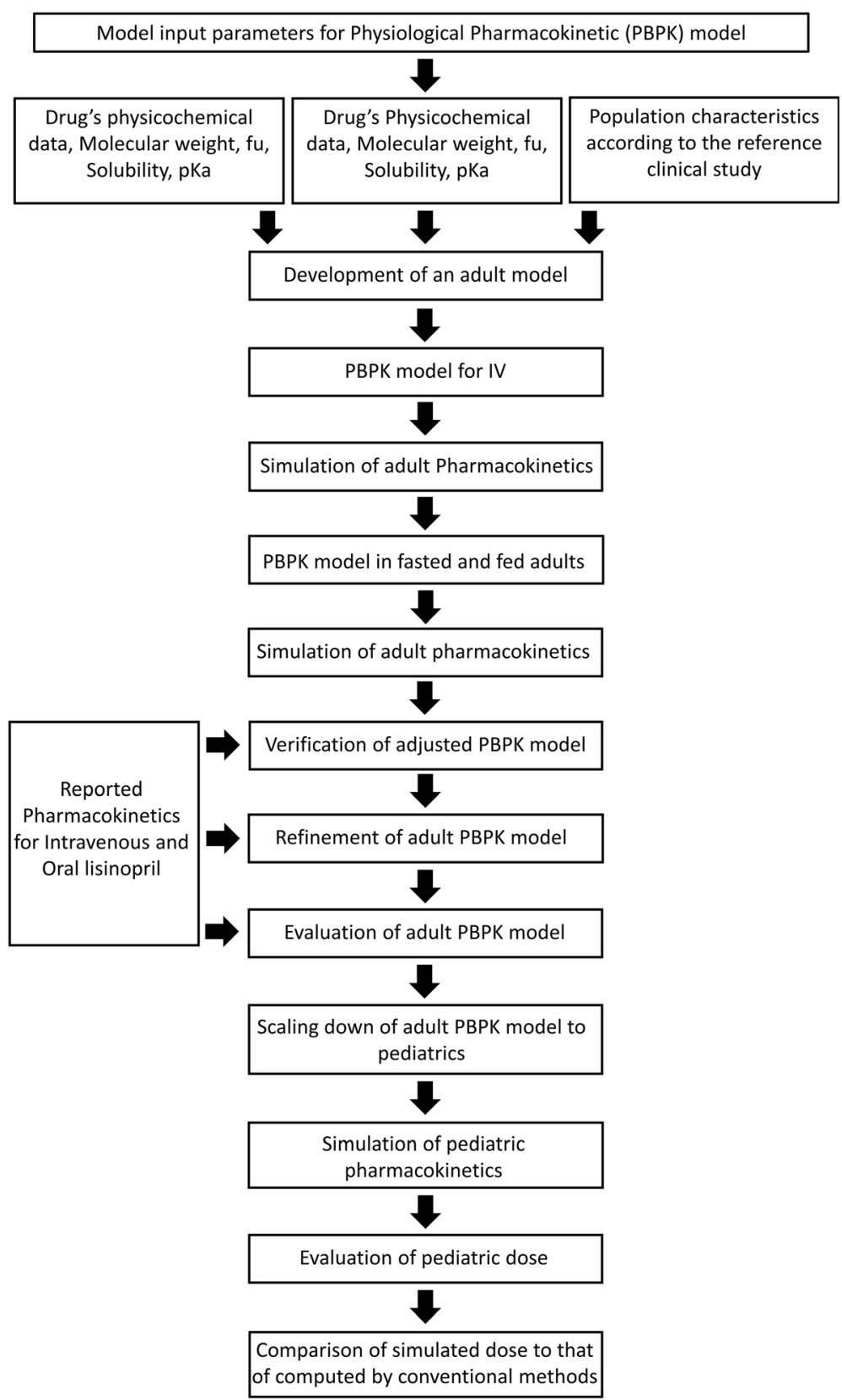

Fig. 1 Developmental strategy for lisinopril PBPK model 
Table 1 Physiological and biological input parameters for PK-Sim Simulation

\begin{tabular}{|c|c|c|c|c|}
\hline \multicolumn{2}{|c|}{ Parameters/Properties } & \multirow{2}{*}{$\begin{array}{l}\text { Values used } \\
-1.22\end{array}$} & \multirow{2}{*}{$\begin{array}{l}\text { Reference values } \\
-1.22\end{array}$} & \multirow{2}{*}{$\frac{\text { References }}{[36]}$} \\
\hline Physicochemical & Lipophilicity (Log P) & & & \\
\hline & Plasma protein binding & Does not bind & & {$[37]$} \\
\hline & Molecular weight & $405.48 \mathrm{~g} / \mathrm{mol}$ & & [38] \\
\hline & Pka & 2.5 & 2.5 (at pH 7) & [36] \\
\hline & Solubility $(\mathrm{mg} / \mathrm{L})$ at reference $\mathrm{pH}$ & 97000 & 97000 & [39]. \\
\hline \multirow[t]{3}{*}{ Biological } & Renal clearance & $0.56 \mathrm{ml} / \mathrm{min} / \mathrm{kg}$ & $\begin{array}{l}47 \pm 8.3 \mathrm{ml} / \mathrm{min} \\
2.82 \pm 0.0083 \mathrm{~L} / \mathrm{h}\end{array}$ & [40] \\
\hline & Metabolism & - & No metabolism & [30] \\
\hline & Elimination & Renal route & Renal route & [30] \\
\hline
\end{tabular}

Table 2 Characteristics of the healthy population used for lisinopril PBPK model development

\begin{tabular}{|c|c|c|c|c|c|c|}
\hline Population Ethnicity & Population Size (n) & Proportion of female & Age (years) & $\begin{array}{l}\text { Dose } \\
(\mathrm{mg})\end{array}$ & Application & References \\
\hline \multirow[t]{3}{*}{ European } & 12 & 0 & $21-34$ & 2.97 & Single IV bolus & {$[41]$} \\
\hline & & & & 5.53 & & \\
\hline & & & & 11.20 & & \\
\hline Caucasians & 18 & 0 & $21-37$ & 20 & Single oral dose & [42] \\
\hline European & 28 & 0 & $18-42$ & 20 & Single oral dose & {$[26]$} \\
\hline European & 8 & 0 & $22-31$ & 20 & Single oral dose for 10 days & {$[41]$} \\
\hline \multirow[t]{3}{*}{ Neonates to Infants } & 100 & 50 & $0.25-1.0$ & 5 & Single oral dose & Current study \\
\hline & & & & 2.5 & & \\
\hline & & & & 1.5 & & \\
\hline \multirow[t]{5}{*}{ Neonates to toddler } & 100 & 50 & $0.25-1.9$ & 20 & Single oral dose & \\
\hline & & & & 10 & & \\
\hline & & & & 5 & & \\
\hline & & & & 2.5 & & \\
\hline & & & & 1.5 & & \\
\hline \multirow[t]{5}{*}{ Pre-schools children } & 100 & 50 & $2-5$ & 20 & Single oral dose & \\
\hline & & & & 10 & & \\
\hline & & & & 5 & & \\
\hline & & & & 2.5 & & \\
\hline & & & & 1.5 & & \\
\hline \multirow[t]{5}{*}{ School children } & 100 & 50 & $5-12$ & 20 & Single oral dose & \\
\hline & & & & 10 & & \\
\hline & & & & 5 & & \\
\hline & & & & 2.5 & & \\
\hline & & & & 1.5 & & \\
\hline \multirow[t]{2}{*}{ Adolescent } & 100 & 50 & $12-16$ & 20 & Single oral dose & \\
\hline & & & & 10 & & \\
\hline
\end{tabular}


(mean of 21 and 37) years was created for PBPK modeling of $20 \mathrm{mg}$ lisinopril.

- Population ethnicity, age, weight and height: Population characteristics such as ethnicity, age, weight, and height of the entire population were created according to the values given in the reference study [42]. The PK-Sim-default values for ideal body weight (IBW) and heights for reference age range (21 to 37) were used during creation of population. A standard deviation of $\pm 10 \%$ was entered for the values of heights.

- Expression level of transporter: Lisinopril is a substrate for the efflux peptide transporter-1, which is maximally expressed in duodenum and jejunum and less in ileum and colon present at the brush border of the small intestine [43]. Taking the above into account, for the creation of population, the expressed level of the transporter was taken as 100\% in the PK-Sim data base.

- Input physiological and biological parameters: The required input physiochemical and biological parameters of lisinopril are given in Table 1.

- Dose of lisinopril: In line with the reference clinical study of lisinopril [42], a single dose tablet of $20 \mathrm{mg}$ lisinopril was set as the administration protocol and the pediatric dose was determined by graded decremental doses to obtain a range of optimized dose.

- Meal calories for fed state: For the fed state, an event of $524 \mathrm{kcal}$ meal was set according to reference [42]. Based on the above protocols, simulations for fasting and fed states were created for the whole population.

- Release pattern: In the formulation building block of PK-Sim, lint type release was entered as the type of drug release. The lint type release, the built- in node of PK-Sim also requires the time interval, as input at which a dosage form releases $80 \%$ of the drug. For this purpose, a compendial standard time of $30 \mathrm{~min}$ for $80 \%$ lisinopril release from the tablet was used as input [44].

- Intestinal permeability: The PK-Sim default value for intestinal permeability was adjusted manually in order to obtained same fraction of drug absorbed, peak blood concentration, bioavailability and area under the curve. The manual adjustment of intestinal permeability has also been supported in the literature to obtain matched pharmacokinetic parameters with the reference [30]. The adjustment of intestinal permeability for the prediction of the desired fraction absorbed in this study was in compliance with the previous report [14]. The adjusted value of human intestinal permeability was used in all simulations for adult and pediatric populations.
- Gastric emptying time: The default mean values of gastric emptying time and small intestine transit time were used in the prediction of the pharmacokinetics of each virtual population.

- Renal clearance: The optimized value of renal clearance was obtained through parameter identification function of PK-Sim for simulated pharmacokinetic profiles of lisinopril after an oral dose in fed and fasted states. Finally, the developed adult PBPK model was validated by comparing the predicted pharmacokinetic parameters to the reference pharmacokinetic parameters.

\section{Validation of PBPK models for adult IV and oral lisinopril pharmacokinetics}

For validation of the PBPK model, the predicted pharmacokinetic parameters for three different intravenous bolus doses and multiple dosing were compared to those of the reported clinical study [41]. Similarly, the pharmacokinetic parameters of $20 \mathrm{mg}$ lisinopril in fed and fasting states were compared to the reported pharmacokinetic parameters $[26,41,42]$. This validated PBPK model was used for development of the pediatric PBPK model for computation of the pediatric dose.

\section{Development of pediatric PBPK model}

For the development of pediatric oral PBPK model for lisinopril, the validated adult PBPK model was scaled down to the pediatric populations of age $0-16$ years [14]. The pediatric population was grouped, according to the standard age into, neonates to infants, infants to toddler, children of pre-school age, children of school age and adolescents by taking into the account of the age-related physiological changes in children. Each virtual pediatric group consisted each of 50 females and males. During creation of virtual pediatric population and simulation of PBPK model, physiological information related to this age group (0-16 years), including blood flow to different organs, GIT radius, length and effective surface area were scaled by PK-Sim itself according to the age. Other scalable parameters, gastric emptying time, intestinal transit time, and gastric $\mathrm{pH}$, were set at the default values.

The demographic characteristics of the virtual pediatric population used for the model development are given in Table 2. The pharmacokinetics parameters of a single 20 $\mathrm{mg}$ adult dose of lisinopril were simulated in pediatric group, i.e., II (Infants to toddler), III (pre-school age children), IV (school age children), and V (adolescent) based on age. As expected, the values of PK parameters at the adult dose were higher. Thus, the PK parameters were re-calculated by decreasing the doses from $20 \mathrm{mg}$ to $10 \mathrm{mg}$, $5 \mathrm{mg}, 2.5 \mathrm{mg}$ and $1.5 \mathrm{mg}$ which corresponded to a dose reduction of $50,75,87.5$ and $92.5 \%$, respectively to accomplish the age-specific desired PK profiles and parameters in 
Group II, III, IV and V. The PK profile and parameters of lisinopril for neonates to infants (group I) were calculated at doses of 5, 2.5, 1.5 and $1 \mathrm{mg}$.

\section{Results}

\section{Simulated pharmacokinetic profiles of lisinopril after} doses and protocols

Simulated plasma concentration profiles compared to the reported profiles and pharmacokinetic parameters for the three different single IV doses in this study are shown Fig. 2 and Table 3, respectively. For fasting condition, the predicted plasma concentration profiles in Caucasian adult healthy male volunteers of age 21-37 (mean $=29$ ) years, after $20 \mathrm{mg}$ of lisinopril single dose, are shown in Fig. 3a and b while for the fed condition, these are shown in Fig. 3c. Table 3 shows the predicted peak lisinopril concentration $\left(\mathrm{C}_{\max }\right)$, time reaching to $\mathrm{C}_{\max }$ $\left(\mathrm{T}_{\max }\right)$ and the area under the curve from time zero to the last time point $\left(\mathrm{AUC}_{0-120 \mathrm{~h}}\right)$ in fasting and fed states after oral $20 \mathrm{mg}$ lisinopril. The simulated plasma level time profiles and parameters were compared to that of the reference study [42]. The simulated profile for the multiple dosing of lisinopril $20 \mathrm{mg}$ OD tablet given for 10 days is given in Fig. 4. Predicted mean minimum plasma concentrations $\left(\mathrm{C}_{\mathrm{min}}\right)$ of lisinopril after $1,2,3,4,5,6,7,8,9$ and 10 days of multiple dosing were $8.40,11.45,12.20,12.40$, $12.48,12.53,12.57,12.60,12.63$ and $12.79 \mathrm{ng} / \mathrm{ml}$, respectively. The predicted $\mathrm{C}_{\min }$ values were compared to values reported in the reference [41]. The $\mathrm{C}_{\min }$ is the drug concentration just prior to the administration of next dose and exhibits, along with other factors the drug equilibration with tissues [45]. We reported $C_{\min }$ because this parameter was referred in the reference study [41], generally more frequently reported, and considered to be less varied, accurate, and reliable [45].

\section{Simulated pharmacokinetics profiles in healthy pediatric population}

The trigger to start dose from $20 \mathrm{mg}$ of lisinopril was a previous clinical study [42], which was used as reference
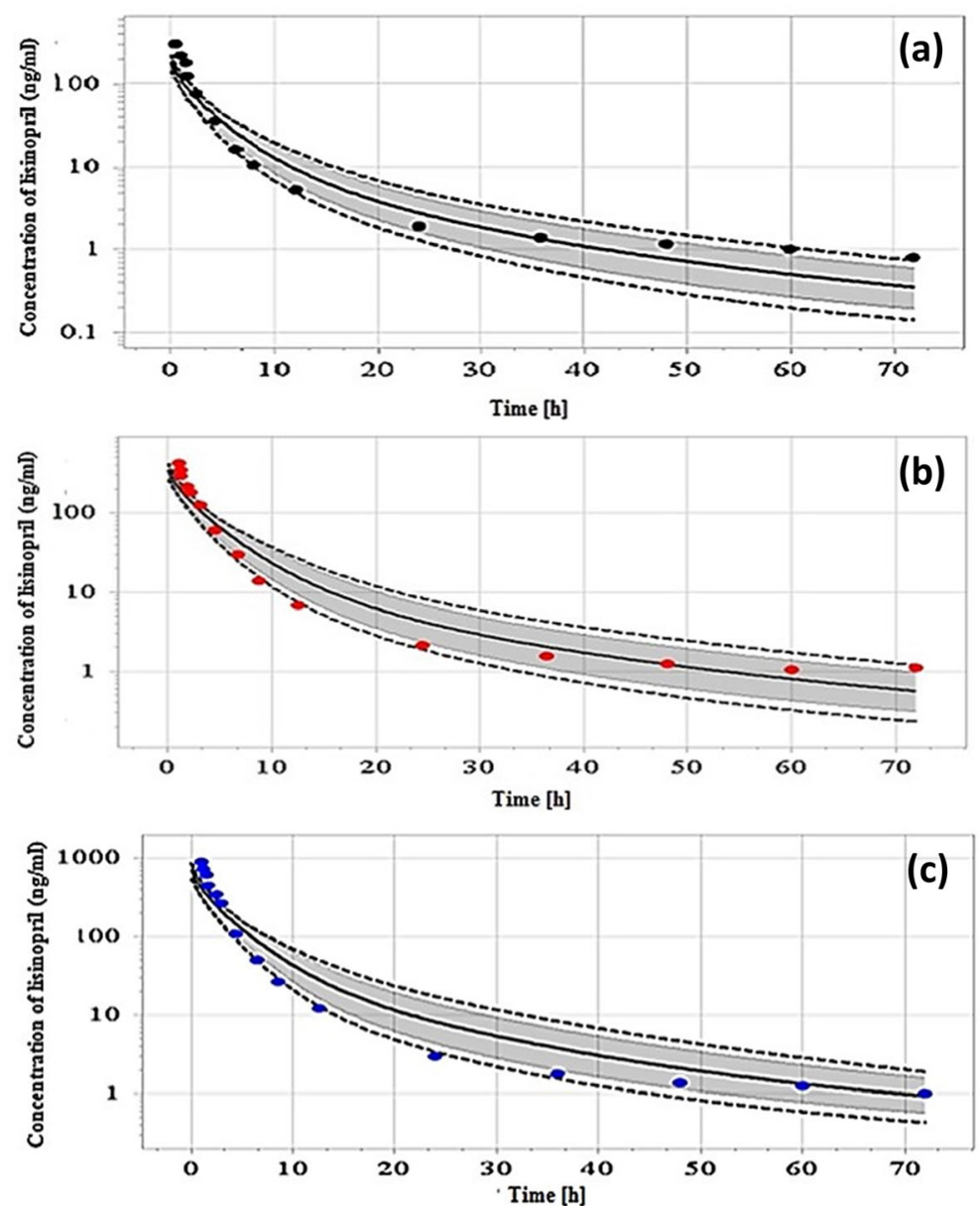

Fig. 2 Predicted plasma concentration time profile shown as solid line and observed data of IV bolus doses: a $2.97 \mathrm{mg}$ as black dots, b $5.53 \mathrm{mg}$ as red dots and $\mathbf{c} 11.20 \mathrm{mg}$ as blue dots. Dotted lines show minimum and maximum value and shaded area shows 5th and 95th percentile 
Table 3 Predicted pharmacokinetic parameters of lisinopril after IV and oral dose administration

\begin{tabular}{|c|c|c|c|c|c|c|c|c|c|}
\hline \multirow[t]{2}{*}{ Ethnicity } & \multirow[t]{2}{*}{ Protocol } & \multirow{2}{*}{$\begin{array}{l}\text { Dose } \\
\text { OD } \\
\text { (mg) }\end{array}$} & \multicolumn{2}{|c|}{$\mathrm{C}_{\max }(\mathrm{ng} / \mathrm{ml})$} & \multicolumn{2}{|l|}{ Tmax (h) } & \multicolumn{2}{|c|}{$\mathrm{AUC}_{\mathrm{o-t}}(\mathrm{ng} \cdot \mathrm{h} / \mathrm{ml})$} & \multirow[t]{2}{*}{ References } \\
\hline & & & Observed & $\begin{array}{l}\text { Predicted } \\
\text { (Mean) }\end{array}$ & Observed & $\begin{array}{l}\text { Predicted } \\
\text { (Mean) }\end{array}$ & Observed & $\begin{array}{l}\text { Predicted } \\
\text { Min-Max }\end{array}$ & \\
\hline \multirow[t]{3}{*}{ European } & \multirow[t]{3}{*}{ IV dose } & 2.97 & - & 182.3 & - & 0.1 & $682 \pm 156^{a}$ & $403-848.9$ & \multirow[t]{3}{*}{ [41] } \\
\hline & & 5.53 & - & 347.2 & - & 0.1 & $1026 \pm 123^{\mathbf{a}}$ & 753.9-1598 & \\
\hline & & 11.2 & & 707 & & 0.1 & $1884 \pm 107^{\mathbf{a}}$ & $1453-3100$ & \\
\hline \multirow[t]{2}{*}{ Caucasians } & Oral (Fasting) & 20 & $86 \pm 48$ & 65.52 & $6.2 \pm 1.1$ & 6.15 & $1231 \pm 620^{\mathbf{b}}$ & $495-2097.6$ & \multirow[t]{2}{*}{ [42] } \\
\hline & Oral (Fed) & 20 & $69 \pm 19$ & 58.9 & $6.8 \pm 1$ & 7.6 & $1029 \pm 254^{\mathbf{b}}$ & $525-2124.7$ & \\
\hline European & Oral (Fasting) & 20 & $79.8 \pm 39.4$ & 69.32 & $6.5 \pm 1.7$ & 5.6 & $992.8 \pm 520^{\mathbf{a}}$ & $556.7-2298$ & [26] \\
\hline
\end{tabular}

$\mathrm{AUC}_{0-\mathrm{t}}{ }^{\mathrm{a}}$ : Area under the curve from time zero to $72 \mathrm{~h}$

$\mathrm{AUC}_{0-\mathrm{t}}$ b: Area under the curve from time zero to $120 \mathrm{~h}$
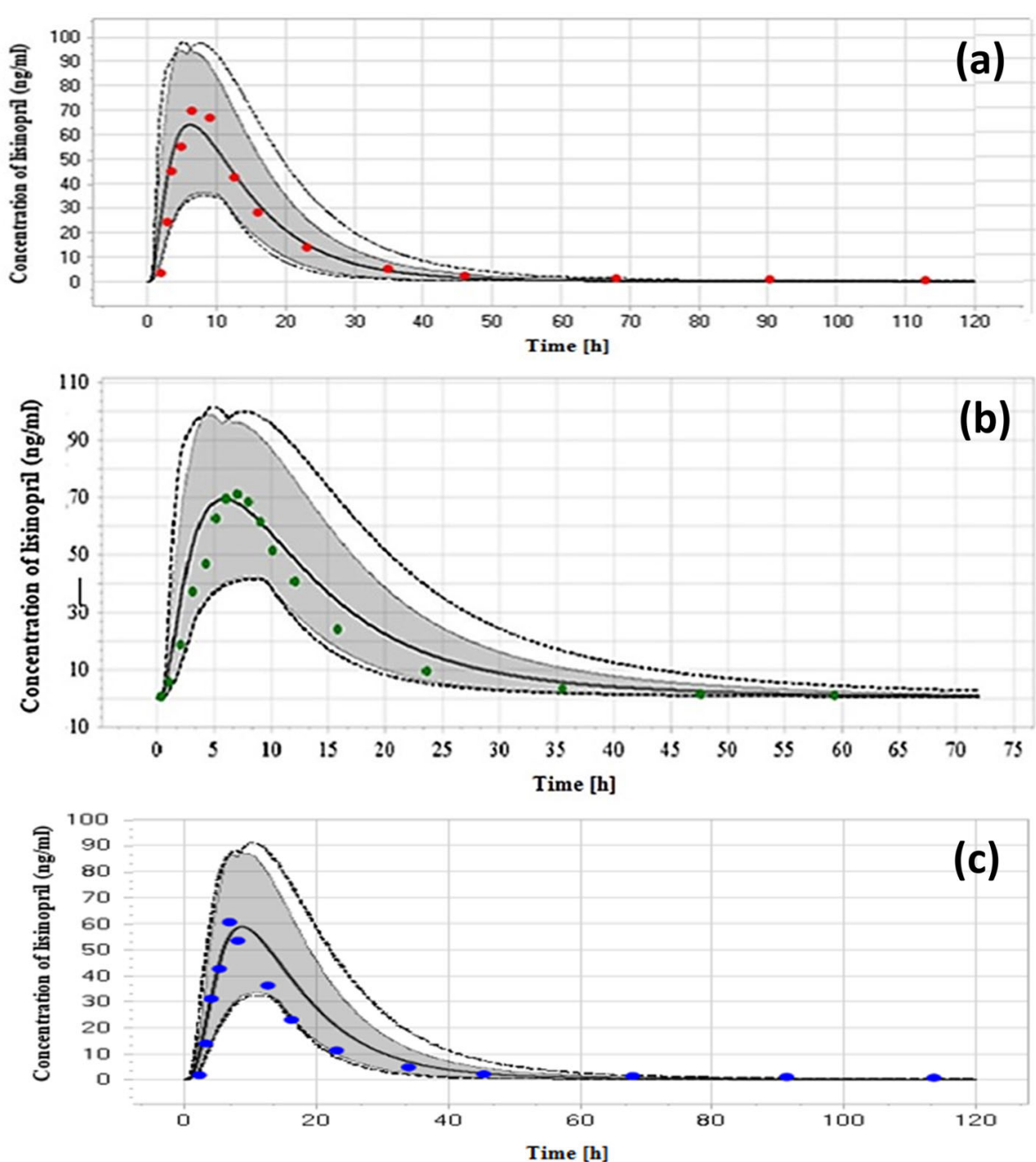

Fig. 3 Predicted plasma concentration-time profiles of lisinopril shown as solid line and observed data in fasting as red and green dots (a) and (b), and fed state as blue dots (c) after $20 \mathrm{mg}$ oral single lisinopril dose in healthy adults according to reported clinical studies [26, 30]. Dotted lines show minimum and maximum values while shaded area shows 5th and 95th percentiles 

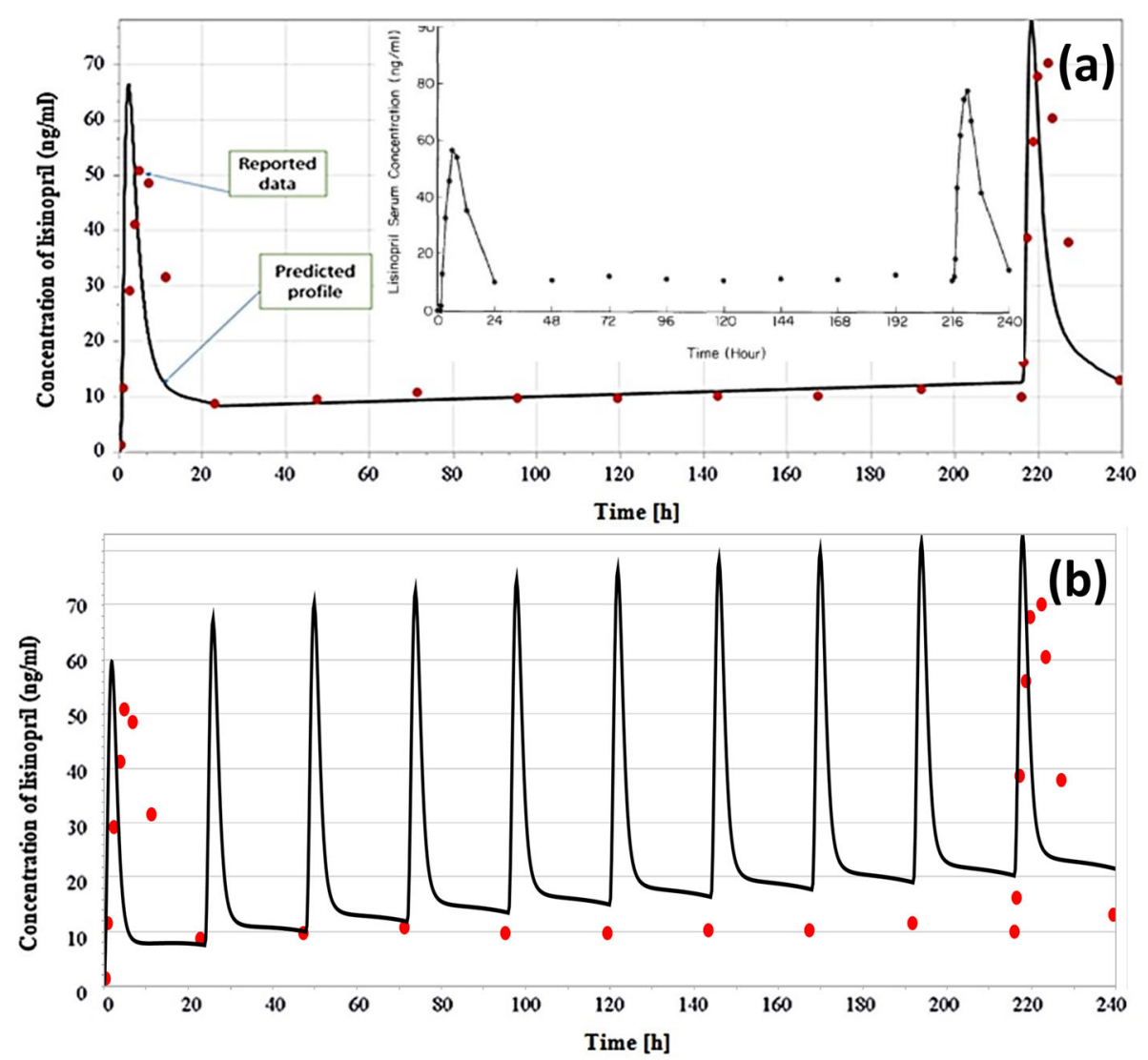

Fig. 4 Predicted plasma concentration profile of lisinopril shown as black line and observed data as red dots after 10 multiple oral doses, (q24 h): a based on reference study [41], given in inset after only 1st and 10th doses and, $\mathbf{b}$ complete profile after 10 daily doses, predicted as black line and observed as red dot

for adult model development. From this adult dose, the pediatric dose was determined by graded decremental doses of $50,75,87.5$ and $92.5 \%$ in order to obtain therapeutic doses. The predicted doses for specific age group were compared to that of the doses calculated using conventional methods (Table 5) and those reported in previous studies. The plasma concentration profile of lisinopril for pediatric population simulated at adult dose $(20 \mathrm{mg})$ and after graded dose reduction of 50, 75, 87.5 and $92.5 \%$ of the adult dose (i.e., $10 \mathrm{mg}, 5 \mathrm{mg}, 2.5 \mathrm{mg}$ and $1.5 \mathrm{mg}$ ) is shown in Fig. $5 \mathrm{a}, \mathrm{b}, \mathrm{c}, \mathrm{d}$ and e, respectively. The simulated $\mathrm{C}_{\max }, \mathrm{T}_{\max }$ and $\mathrm{AUC}_{0-120 \mathrm{~h}}$ have been given in Table 4. In neonates to infants, the simulated plasma concentration profile and $\mathrm{AUC}_{0-120 \mathrm{~h}}$ after doses of $5 \mathrm{mg}, 2.5 \mathrm{mg}, 1.5 \mathrm{mg}$ and $1 \mathrm{mg}$ are shown in Fig. 6 and Table 4.

\section{Discussion}

\section{Reasons for selection of lisinopril}

Lisinopril follows simple pharmacokinetics, shows no protein binding [31], does not undergo metabolism [25] and is excreted unchanged through renal route [30]. The
GFR of such drugs is not affected by age, as it reaches to above $90 \%$ of adult level at the age of 1 year [46], thus clearance is also unaffected with age [47]. The above features of the drug could help easy PBPK model development and reliable validation of the simulated findings. Furthermore, findings of a real-time studies in hypertensive and kidney transplant pediatric recipients for their pharmacokinetics parameters [48] are available, which could be matched with the simulated values in the present study for authenticated simulation by PBPK modeling.

\section{Simulated pharmacokinetic profiles of lisinopril after three different single IV bolus doses}

The predicted plasma concentration time profiles and the pharmacokinetic parameters for three IV doses were compared to the values reported in a study taken as reference [41]. In the reference study, the plasma level time profiles (Fig. 2) were predicted after three intravenous bolus doses (2.97, 5.53, and $11.20 \mathrm{mg}$ ) for 12 European healthy male adults, age 21 to 34 year. The pharmacokinetics simulation with IV application provides its disposition kinetics without the interference of complexities arising from 

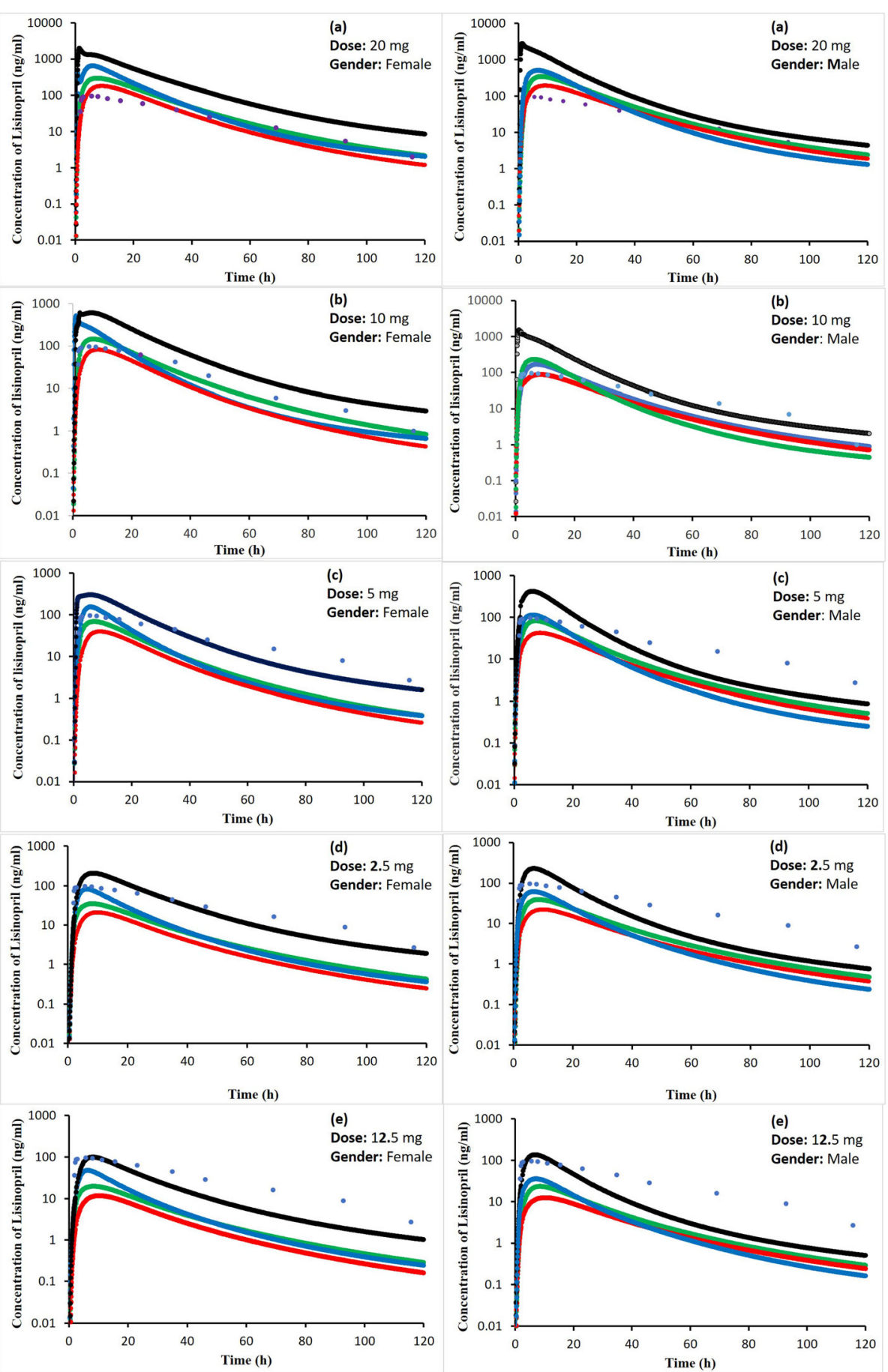

Fig. 5 Simulated lisinopril plasma concentration profiles after administration of: (a) $20 \mathrm{mg}$ (b), $10 \mathrm{mg}$ (c), $5 \mathrm{mg}$ (d), $2.5 \mathrm{mg}$ and, (e) $1.5 \mathrm{mg}$ for both genders in infants to toddler as black line, pre-schooled children as blue line, schooled children as green line, adolescent as red line and observed experimental data in healthy adults as dots

absorption [14]. The predicted plasma concentration profiles (Fig. 2) and pharmacokinetic parameters (Table 3) for the three IV doses were comparable to the reference study [41]. The predicted value of $\mathrm{V}_{\mathrm{ss}}$ in this study after IV protocol was comparable to its reported value (i.e.,
$0.89 \mathrm{~L} / \mathrm{Kg}$ ) in the reference study [49]. All model input parameters which resulted into the similar visual depiction of pharmacokinetic profiles and parameters to that of the above reference study along with the other parameters influencing absorption (i.e., intestinal permeability, gastric 
Table 4 Predicted pharmacokinetic parameters of lisinopril after different single oral dose administration to pediatric population

\begin{tabular}{|c|c|c|c|c|c|c|c|c|c|c|}
\hline $\begin{array}{l}\text { PK } \\
\text { parameter } \\
\text { 20mg }\end{array}$ & $\begin{array}{c}\text { Neonates to } \\
\mathbf{M}\end{array}$ & $\begin{array}{r}\text { Infants } \\
F\end{array}$ & $\begin{array}{c}\text { Infants to to } \\
M\end{array}$ & ${ }_{\mathbf{F}}^{\text {diler }}$ & $\begin{array}{l}\text { Pre-school a } \\
\text { M }\end{array}$ & ge & $\begin{array}{c}\text { School-age } \\
\text { M }\end{array}$ & $\mathbf{F}$ & $\begin{array}{c}\text { Adolescent } \\
\text { M }\end{array}$ & $\mathbf{F}$ \\
\hline $\begin{array}{l}\mathrm{C}_{\max } \\
(\mathrm{ng} / \mathrm{ml})\end{array}$ & $\mathrm{NC}^{* *}$ & $\mathrm{NC}^{* * *}$ & $\begin{array}{c}5041 \\
(541-5987)\end{array}$ & $\begin{array}{c}3213 \\
(564-4169)\end{array}$ & $\begin{array}{c}691 \\
(525-1425)\end{array}$ & $\begin{array}{c}2681 \\
(339-1239)\end{array}$ & $\begin{array}{c}445 \\
(305-775)\end{array}$ & $\begin{array}{c}393 \\
(230-679)\end{array}$ & $\begin{array}{c}256 \\
(62-362)\end{array}$ & $\begin{array}{c}244 \\
(87-350)\end{array}$ \\
\hline $\mathrm{T}_{\max }(\mathrm{h})$ & $\mathrm{NC}^{* *}$ & $\mathrm{NC}^{* * *}$ & $\begin{array}{c}8 \\
(1.5-9.5)\end{array}$ & $\begin{array}{c}2 \\
2 \\
(1-8.5)\end{array}$ & $\begin{array}{c}8.5 \\
(7-9.96)\end{array}$ & $\begin{array}{c}2 \\
2 \\
(1.5-12.03)\end{array}$ & $\begin{array}{c}8 \\
8 \\
(7.25-13)\end{array}$ & $\begin{array}{c}9 \\
(7.5-10.5)\end{array}$ & $\begin{array}{c}8 \\
(5-9)\end{array}$ & $\begin{array}{c}8.25 \\
(7-12)\end{array}$ \\
\hline $\begin{array}{l}\mathrm{AUC}_{0.120} \\
\text { (ng.h/ml) } \\
\mathbf{1 0} \mathbf{m g}\end{array}$ & $\mathrm{NC}^{* *}$ & $\mathrm{NC}^{* *}$ & $\begin{array}{c}25181 \\
(8119-51668)\end{array}$ & $\begin{array}{c}28006 \\
(8485-87534)\end{array}$ & $\begin{array}{c}20123 \\
(7031-41270)\end{array}$ & $\begin{array}{c}20129 \\
(7124-48276)\end{array}$ & $\begin{array}{c}13042 \\
(6396-27550)\end{array}$ & $\begin{array}{c}12931 \\
(6258-22860)\end{array}$ & $\begin{array}{c}4186 \\
(1132-8223)\end{array}$ & $\begin{array}{c}4159 \\
(1621-12400)\end{array}$ \\
\hline $\mathrm{C}_{\max }(\mathrm{ng} / \mathrm{ml})$ & $\mathrm{NC}^{* *}$ & $\mathrm{NC}^{* *}$ & $\begin{array}{c}1047 \\
(277-1448)\end{array}$ & $\begin{array}{c}747 \\
(283-2323)\end{array}$ & $\begin{array}{c}392 \\
(260-708\end{array}$ & $\begin{array}{c}3999 \\
(205-572)\end{array}$ & $\begin{array}{c}281 \\
(114-385)\end{array}$ & $\begin{array}{c}166 \\
(142-337)\end{array}$ & $\begin{array}{c}82 \\
(31-171)\end{array}$ & $\begin{array}{c}102 \\
(44-180)\end{array}$ \\
\hline $\mathrm{T}_{\max }(\mathrm{h})$ & $\mathrm{NC}^{* *}$ & $\mathrm{NC}^{* * *}$ & $\begin{array}{c}6.5 \\
(1.5-9)\end{array}$ & $\begin{array}{c}8 \\
(1-9.5)\end{array}$ & $\begin{array}{c}7 \\
(9.03-13.8)\end{array}$ & $\begin{array}{c}3.5 \\
(9.9-14.6)\end{array}$ & $\begin{array}{c}7.5 \\
(8.5-13.25)\end{array}$ & $\begin{array}{c}8 \\
(7.25-13.5)\end{array}$ & $\begin{array}{c}7.5 \\
(5.5-16)\end{array}$ & $\begin{array}{c}8.5 \\
(7.25-9.25)\end{array}$ \\
\hline $\begin{array}{l}\mathrm{AUC}_{0.120} \\
(\mathrm{ng} . \mathrm{h} / \mathrm{ml}) \\
\mathbf{5 m g}\end{array}$ & $\mathrm{NC}^{* *}$ & $\mathrm{NC}^{* *}$ & $\begin{array}{c}12674 \\
(4751-25150)\end{array}$ & $\begin{array}{c}13786 \\
(3399-27091\end{array}$ & $\begin{array}{c}10636 \\
(3974-23170)\end{array}$ & $\begin{array}{c}10829 \\
(3597-24597\end{array}$ & $\begin{array}{c}6419 \\
(3004-13661)\end{array}$ & $\begin{array}{c}6322 \\
(3113-11265)\end{array}$ & $\begin{array}{c}2044 \\
(696-4109)\end{array}$ & $\begin{array}{c}1994 \\
(815-6198)\end{array}$ \\
\hline $\mathrm{C}_{\max }(\mathrm{ng} / \mathrm{ml})$ & $\begin{array}{c}519 \\
(184-809)\end{array}$ & $\begin{array}{c}460 \\
(151-1123)\end{array}$ & $\begin{array}{c}651 \\
(268-2323)\end{array}$ & $\begin{array}{c}575 \\
(231-1692)\end{array}$ & $\begin{array}{c}142 \\
(83-306\end{array}$ & $\begin{array}{c}215 \\
(99-350)\end{array}$ & $\begin{array}{c}82 \\
(70-190)\end{array}$ & $\begin{array}{c}82 \\
(56-167)\end{array}$ & $\begin{array}{c}52 \\
(16-90)\end{array}$ & $\begin{array}{c}48 \\
(22-86)\end{array}$ \\
\hline $\mathrm{T}_{\max }(\mathrm{h})$ & $\begin{array}{c}7 \\
(1.5-9.5)\end{array}$ & $\begin{array}{c}8.5 \\
(1-95)\end{array}$ & $\begin{array}{l}7.25 \\
(1.2-8.2)\end{array}$ & $\begin{array}{c}7.5 \\
(12-1075)\end{array}$ & $\begin{array}{c}10 \\
(8-13.8)\end{array}$ & $\begin{array}{c}10.3 \\
((85-14.6)\end{array}$ & $\begin{array}{c}9 \\
(7-5-132)\end{array}$ & $\begin{array}{c}9.5 \\
(725-13.5)\end{array}$ & $\begin{array}{c}7.5 \\
(5.5-16)\end{array}$ & $\begin{array}{c}8.5 \\
(7.5-9)\end{array}$ \\
\hline $\begin{array}{l}\mathrm{AUC}_{0.120} \\
\text { (ng.h/ml) }\end{array}$ & $\begin{array}{c}5754 \\
(3185-10050)\end{array}$ & $\begin{array}{c}5252 \\
(3248-20091)\end{array}$ & $\begin{array}{c}6358 \\
(1782-6628)\end{array}$ & $\begin{array}{c}6505 \\
(1520-6600)\end{array}$ & $\begin{array}{c}5328 \\
(1662-11471)\end{array}$ & $\begin{array}{c}5467 \\
(1782-12686)\end{array}$ & $\begin{array}{c}3207 \\
(1493-6747)\end{array}$ & $\begin{array}{c}3109 \\
(1552-5611)\end{array}$ & $\begin{array}{c}997 \\
(349-2055)\end{array}$ & $\begin{array}{c}1003 \\
(404-3102)\end{array}$ \\
\hline $2.5 \mathrm{mg}$ & & & & & & & & & & \\
\hline $\mathrm{C}_{\max }(\mathrm{ng} / \mathrm{ml})$ & $\begin{array}{c}332 \\
(142-723)\end{array}$ & $\begin{array}{c}317 \\
(132-782)\end{array}$ & $\begin{array}{c}257 \\
(103-268)\end{array}$ & $\begin{array}{c}185 \\
(80-526)\end{array}$ & $\begin{array}{c}82 \\
(41-152)\end{array}$ & $\begin{array}{c}100 \\
(63-174)\end{array}$ & $\begin{array}{c}66 \\
(34-93)\end{array}$ & $\begin{array}{c}41.4 \\
(27-82)\end{array}$ & $\begin{array}{c}25 \\
(7.9-45)\end{array}$ & $\begin{array}{c}23 \\
(11.2-42)\end{array}$ \\
\hline $\mathrm{T}_{\max }(\mathrm{h})$ & $\begin{array}{c}7 \\
(1.1-9.5)\end{array}$ & $\begin{array}{c}7.5 \\
(1.2 .5)\end{array}$ & 8 & $\begin{array}{c}8.5 \\
(1-9.5)\end{array}$ & $\begin{array}{c}7.5 \\
(0.1425)\end{array}$ & $\begin{array}{l}7.5 \\
(12-15)\end{array}$ & $\begin{array}{c}11 \\
9-135)\end{array}$ & $\begin{array}{c}11 \\
11\end{array}$ & $\begin{array}{c}7.5 \\
(5 .-16)\end{array}$ & $\begin{array}{l}7.5 \\
79-11)\end{array}$ \\
\hline $\begin{array}{l}\mathrm{AUC}_{0-120} \\
\text { (ng.h/ml) }\end{array}$ & $\begin{array}{c}3039 \\
(1585-5036)\end{array}$ & $\begin{array}{c}2717 \\
(1685-9252)\end{array}$ & $\begin{array}{c}2672 \\
(1252-5661)\end{array}$ & $\begin{array}{c}2786 \\
(1149-6237)\end{array}$ & $\begin{array}{c}1(1-1422 \\
1222 \\
(445-3164)\end{array}$ & $\begin{array}{c}(1-1), 13) \\
1313 \\
(327-3284)\end{array}$ & $\begin{array}{c}(y-13.13) \\
966 \\
(744-3316)\end{array}$ & $\begin{array}{c}(10 . / 1-1.10) \\
884 \\
(711-2716)\end{array}$ & $\begin{array}{c}(.0-10) \\
525 \\
(140-1027)\end{array}$ & $\begin{array}{l}(y-11) \\
506 \\
(254-1408)\end{array}$ \\
\hline $1.5 \mathrm{mg}$ & & & & & & & & & & \\
\hline $\mathrm{C}_{\max }(\mathrm{ng} / \mathrm{ml})$ & $\begin{array}{c}208 \\
(85-352)\end{array}$ & $\begin{array}{c}198 \\
(92-424)\end{array}$ & $\begin{array}{c}80 \\
(52-125)\end{array}$ & $\begin{array}{c}83 \\
(50-281)\end{array}$ & $\begin{array}{c}41 \\
(28-102)\end{array}$ & $\begin{array}{c}58 \\
(24-90)\end{array}$ & $\begin{array}{c}38 \\
(21-51)\end{array}$ & $\begin{array}{c}22 \\
(24-55)\end{array}$ & $\mathrm{NC}^{* *}$ & $\mathrm{NC}^{* *}$ \\
\hline $\mathrm{T}_{\max }(\mathrm{h})$ & $\begin{array}{c}7 \\
(6-9.5)\end{array}$ & $\begin{array}{c}7.25 \\
(4-10.25)\end{array}$ & $\begin{array}{c}9 \\
(1.5-9.5)\end{array}$ & $\begin{array}{c}8.5 \\
(1.5-10.5)\end{array}$ & $\begin{array}{c}7.5 \\
(7-1.03)\end{array}$ & $\begin{array}{c}9 \\
(8-12)\end{array}$ & $\begin{array}{c}8 \\
(7-11)\end{array}$ & $\begin{array}{c}8.5 \\
(7.2-11.5)\end{array}$ & $\mathrm{NC}^{* *}$ & $\mathrm{NC}^{* *}$ \\
\hline $\begin{array}{l}\mathrm{AUC}_{0.120} \\
\text { (ng.h/ml) }\end{array}$ & $\begin{array}{c}1715 \\
(958-3105)\end{array}$ & $\begin{array}{c}1707 \\
(1104-5448)\end{array}$ & $\begin{array}{c}1517 \\
(738-3361)\end{array}$ & $\begin{array}{c}1619 \\
(680-3379)\end{array}$ & $\begin{array}{c}761 \\
(265-1834) \\
\end{array}$ & $\begin{array}{c}764 \\
(260-1870)\end{array}$ & $\begin{array}{c}884 \\
(472-1572)\end{array}$ & $\begin{array}{c}996 \\
(502-1342) \\
\end{array}$ & $\mathrm{NC}^{* *}$ & $\mathrm{NC}^{* *}$ \\
\hline $\begin{array}{l}1 \mathrm{mg} g \\
\mathrm{C}_{\max }(\mathrm{ng} / \mathrm{ml})\end{array}$ & $\begin{array}{c}129 \\
(56.8-240)\end{array}$ & $\begin{array}{c}122 \\
(56.9-283)\end{array}$ & $\begin{array}{c}54 \\
(40-171)\end{array}$ & $\begin{array}{c}53 \\
(33-181)\end{array}$ & $\mathrm{NC}^{* *}$ & $\mathrm{NC} * *$ & $\mathrm{NC}^{* *}$ & $\mathrm{NC}^{* *}$ & $\mathrm{NC}^{* *}$ & $\mathrm{NC}^{* *}$ \\
\hline $\mathrm{T}_{\max }(\mathrm{h})$ & $\begin{array}{c}7 \\
(6.2-9.5)\end{array}$ & $\begin{array}{c}7.5 \\
(4-10.5)\end{array}$ & $\begin{array}{c}9.2 \\
(9-11.5)\end{array}$ & $\begin{array}{c}9.5 \\
(1.5-11.5)\end{array}$ & $\mathrm{NC}^{* *}$ & $\mathrm{NC}^{* *}$ & $\mathrm{NC}^{* *}$ & $\mathrm{NC}^{* *}$ & $\mathrm{NC}^{* *}$ & $\mathrm{NC}^{* *}$ \\
\hline $\begin{array}{l}\mathrm{AUC}_{0.120} \\
(\mathrm{ng} . \mathrm{h} / \mathrm{ml})\end{array}$ & $\begin{array}{c}1407 \\
(726-1926)\end{array}$ & $\begin{array}{c}1253 \\
(679-3605)\end{array}$ & $\begin{array}{c}439 \\
(180-1211)\end{array}$ & $\begin{array}{c}465 \\
(143-1300)\end{array}$ & $\mathrm{NC}^{* *}$ & $\mathrm{NC}^{* *}$ & $\mathrm{NC}^{* *}$ & $\mathrm{NC}^{* *}$ & $\mathrm{NC}^{* * *}$ & $\mathrm{NC}^{* *}$ \\
\hline
\end{tabular}

* [42], $N C^{* *}$ Not Calculated

The pharmacokinetic parameters were predicted at different doses to obtain values in pediatrics, similar to the reference adult values predicted at $20 \mathrm{mg}$, such as $C_{\max } 86 \pm 48$ (range 38-124) ng/ml, $T_{\max } 6.2 \pm 1.1$ (range 5.1-7.3) $\mathrm{h}$ and $A U C_{0-120} 1231 \pm 620$ (range 611-1851) $\mathrm{ng} . \mathrm{h} / \mathrm{ml}$. The yellow color indicates falling of lower range of predicted $C_{\max }$ and $A \cup C_{0-120}$ within the range of reference values, Blue color shows falling of lower and mean value of predicted $A \cup C_{0-120}$ in reference range, while green color demonstrates dose at which maximum value of $C_{\max }$ and $A U C_{0-120}$ falls in reference range

emptying time and intestinal transit time) were employed for the simulation after oral dose in the next step.

\section{Simulated pharmacokinetics of lisinopril after an oral dose in fed and fasted states}

Input of the model-produced value of intestinal permeability, $1.89 \mathrm{E}^{-9} \mathrm{~cm} / \mathrm{min}$, resulted $25 \%$ lesser bioavailability for lisinopril than reported bioavailability (with 6$60 \%$ inter individual variability) [29]. Literature supports redefining of parameters, particularly value of intestinal permeability in order to accomplish similar-to-desired pharmacokinetic profile $[14,50]$. Thus, intestinal permeability was adjusted from range of permeability values entered in parameters identification option of PK-Sim. As a result, permeability of $3.6 \mathrm{E}^{-7} \mathrm{~cm} / \mathrm{min}$ minimized variation between the fitted and reference bioavailability profiles [42]. Lisinopril shows a large inter-individual variability in a population after equal doses, study reports [51]. In the present study, bioavailability of lisinopril remained unaffected in presence of food, in line with previous report [37].
Two previous studies on lisinopril in fasting state [26, 30] could be used for authentication and validation of developed PBPK model in this study. Since both studies produced comparable pharmacokinetic parameters after same lisinopril dose in fasting adults therefore, for further prediction of pediatric dose, only one study [30] was employed as reference. The simulated $\mathrm{C}_{\max }, \mathrm{T}_{\max }$ and $\mathrm{AUC}_{0-120 \mathrm{~h}}$ of lisinopril after oral $20 \mathrm{mg}$ lisinopril were comparable to values reported by Beermann 1988. The predicted $\mathrm{C}_{\max }$ in fasting and fed conditions $(88.52 \mathrm{ng} / \mathrm{ml}$ and $61.36 \mathrm{ng} / \mathrm{ml}$, respectively) were comparable to the reported values $(86 \pm 48 \mathrm{ng} / \mathrm{ml}$ and $69 \pm 19 \mathrm{ng} / \mathrm{ml})$ in same conditions [30]. Similarly, the predicted $\mathrm{T}_{\max }$ values in fasting and fed conditions ( $6.15 \mathrm{~h}$ and $7.6 \mathrm{~h}$, respectively), were also found comparable (Fig. 3 and Table 3).

\section{Simulated pharmacokinetic profile after multiple oral dosing of lisinopril}

Multiple dosing of lisinopril $20 \mathrm{mg}$ OD tablet for 10 days generated comparable plasma level profile (Fig. 4) and minimum plasma concentration $\left(\mathrm{C}_{\min }\right)$ to the reference [41]. 

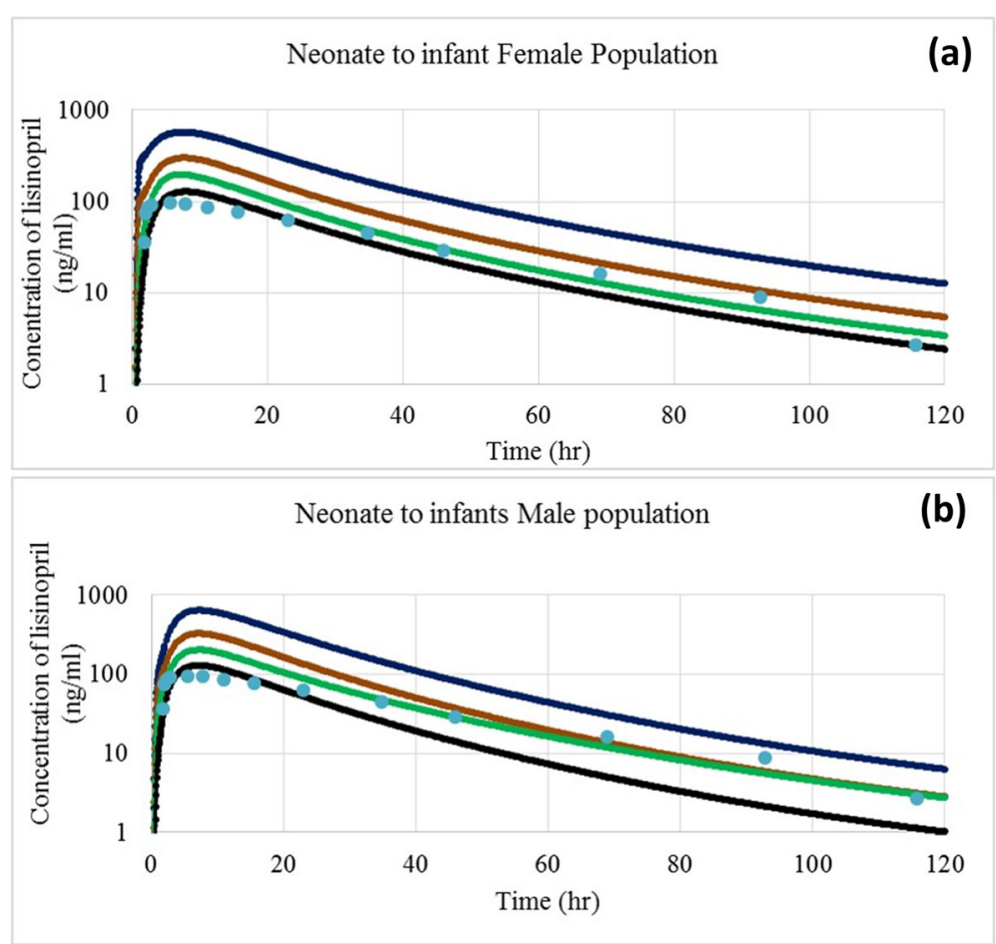

Fig. 6 Simulated plasma concentration profiles of lisinopril in neonates to infants: a female and $\mathbf{b}$ male at different doses, 5 mg as blue line, 2.5 $\mathrm{mg}$ as brown line, $1.5 \mathrm{mg}$ as green line, and $1 \mathrm{mg}$ as black line and observed experimental data in healthy adults as dots

\section{Predicted lisinopril pediatric dose}

In neonates to infants and in infants to toddlers, the desired PK parameters were obtained at population dose of 1.0 and 1.5 to $2.5 \mathrm{mg}$ shown in Table 4 and Figs. 5 and 6 , respectively, while for the pre-school and school children, the predicted dose were 1.5, 2.5 and $5 \mathrm{mg}$ by considering the mean, minimum and maximum value of $\mathrm{C}_{\max }, \mathrm{T}_{\max }$ and $\mathrm{AUC}_{0_{-}}$ $120 \mathrm{~h}$. In adolescents, the predicted doses were 5 and $10 \mathrm{mg}$. The simulated Plasma time profiles (Figs. 5 and 6) and doses for all groups of children were compared to the doses calculated by Young's rule (age), Clark's rule (weight), and on weight (mg per $\mathrm{kg}$ ) basis and according to the BSA of child using $20 \mathrm{mg}$ as adult reference dose (Table 5). These formulae for calculation of a child dose are based on physiological covariates including age, weight, height or BSA.
The modelled pediatric dose for infant (1 year), 1.5$2.5 \mathrm{mg}$ was similar to that found by Young's and Clark's formula. For the pre-school, 5-year old child, Young, Clark, weight-based and BSA-based formulae overestimated dose as 5.88, 5.0, 5.0 and $8.5 \mathrm{mg}$, respectively as compared to a remarkably lesser predicted dose of 2.5 mg. Similarly, in 12-year old child the doses given by Young and Clark, weight-based and BSA-based formulae, respectively were $10,12,11$ and $13 \mathrm{mg}$, higher as compared to the model-computed dose, 1.5, 2.5 and 5 mg. The PBPK model proposed therapeutic dose range of lisinopril in the pediatric population of age 5 to 16 years as $1.5 \mathrm{mg}$ to $10 \mathrm{mg}$.

Previous reports supported the present findings. According to the literature the dose of lisinopril in

Table 5 Doses calculated for children of different ages by using empirical formulas of pediatric dose calculation

\begin{tabular}{|c|c|c|c|c|c|c|c|c|c|}
\hline \multirow{3}{*}{$\begin{array}{l}\text { Pediatric } \\
\text { Population }\end{array}$} & \multicolumn{8}{|c|}{ Pediatric dose calculation methods } & \multirow{3}{*}{$\begin{array}{l}\text { PK-Sim } \\
\text { Dose } \\
\text { (mg) }\end{array}$} \\
\hline & \multicolumn{2}{|l|}{ Young's rule } & \multicolumn{2}{|l|}{ Clark's rule } & \multicolumn{2}{|c|}{ Weight (mg/kg)-based } & \multicolumn{2}{|c|}{ BSA-based } & \\
\hline & Age (years) & Dose (mg) & Weight (pound) & Dose $(\mathrm{mg})$ & Weight (kg) & Dose $(\mathrm{mg})$ & $\begin{array}{l}\mathrm{BSA} \\
\left(\mathrm{m}^{2}\right)\end{array}$ & $\begin{array}{l}\text { Dose } \\
(\mathrm{mg})\end{array}$ & \\
\hline Infants to toddler & 1 & 1.53 & 22 & 2.93 & 10 & 2.85 & 0.43 & 4.73 & 1.0 to 2.5 \\
\hline Preschool & 5 & 5.88 & 37 & 5 & 17 & 5 & 0.78 & 8.5 & 1.5 to 5 \\
\hline School age & 12 & 10 & 88 & 12 & 40 & 11 & 1.25 & 13 & 1.5 to 5 \\
\hline Adolescent & 17 & 12 & 132 & 18 & 60 & 17 & 1.58 & 17 & 2.5 to 10 \\
\hline
\end{tabular}

${ }^{\mathrm{a}}$ Same doses were calculated for male and female children 
children of age 6 to 16 years is to be started from the $2.5 \mathrm{mg}$, which should then be increased gradually to achieve the antihypertensive effect [52]. A study in hypertensive children of age 7-17 years with stable kidney function following transplant concluded that lisinopril follows linear response on increasing the dose [24]. The lisinopril should be started from a low dose, i.e., $0.1 \mathrm{mg} / \mathrm{kg}$ which could be adjusted according to the response of patients. Our doses in the healthy pediatric population (Table 4) were comparable to the above findings. While FDA has approved the use of lisinopril for hypertensive children above 6 year and or who receive the kidney transplant with a starting dose from $5 \mathrm{mg}$ to maximum dose of $40 \mathrm{mg}$ [22]. Another study in hypertensive pediatric patients suggested $2.5 \mathrm{mg}$ once daily dose of lisinopril in children of less than 6 year age with body weight less than $25 \mathrm{~kg}$ and $5 \mathrm{mg}$ as dose for age greater than 6 years and body weight 25 to $45 \mathrm{~kg}$. For children of age greater than 6 years and weight greater than $45 \mathrm{~kg}$, the suggested dose was $10 \mathrm{mg}$ [53] which was in line with the present findings (Table 4). The present dose was also supported by another study where lisinopril showed maximum antihypertensive efficacy at dose of $5 \mathrm{mg}$ in children of 6-16 years age [23].

Mean simulated $\mathrm{T}_{\max }$ of lisinopril for neonates to infants was, respectively 6 and $4 \mathrm{~h}$ in females and males, which was also comparable to that reported for children [25]. Dose predicted with PBPK model for an infant (1 year), preschool (5 years) and school (12 years) child were comparable to dose calculated by Young's rule. While dose calculated by Clark's rule, weight $(\mathrm{mg} / \mathrm{kg})$ based equation and BSA-based formula were higher for infants, toddler, pre-school age, school age and adolescent population as compared to respective dose obtained through PBPK modeling. As there is 6 to $60 \%$ of variability for lisinopril at all reported dose ranges of 5-50 $\mathrm{mg}$, therefore initially, a lower dose must always be started. Another limitation of the above formulae is their inability to compute dose separately, for male or female's child coupled with ignorance of the physiological differences in different age groups. However, requirement of adjustments of intestinal permeability for prediction of pharmacokinetic parameters during simulation necessitated the validation of the current PBPK modeling. Nonetheless, the simulated findings seemed to be reliable as were supported by the following: (A) consistent findings of present simulations in healthy adults and with a study in hypertensive and kidney transplant pediatric recipients [48], (B) comparable simulated pharmacokinetic parameters in adults to that of reported after lisinopril administered to different pediatric subpopulations in doses $0.1-0.2 \mathrm{mg} / \mathrm{kg}(C)$ existence of a strong correlation of GFR-dependent drug clearance to BSA and, as a result comparable PBPK model predicted and BSA-based doses of lisinopril as GFR remains unaffected with age, since it reaches $>90 \%$ of adult levels by age 1 [54], and lisinopril clearance remains unaffected with age, as lisinopril is not metabolized, and excreted largely unchanged through GFR, and (D) demonstration of drug as effective, safe and well tolerated when dosed according to recommendations in previous investigations consistent with the findings of this study. Dose computation though PBPK approach could be reliable if extensive adult pharmacokinetic data is available. Furthermore, the effective application of the PBPK for the dose calculation in pediatric patients requires dose confirmation in the real clinical setting.

\section{Conclusion}

The PBPK models using dose decremental method could be employed for the prediction of lisinopril pediatric dose, particularly by taking into consideration of the age-led changes in specific pediatric subpopulations. The PBPK approach is seemed to predict also the gender-specific doses which is not possible in conventional methods. Dose extrapolation in children solely based on age or weight may not be accurate and may potentially be harmful to children. PBPK approach may have more dose prediction potentials as it considers the physiological changes related to age. However, the finding of this study could be translatable clinically only after a real time pharmacokinetic or clinical study in such patients with the predicted doses.

\section{Abbreviations \\ AUC : Area under curve; BSA: Body Surface Area; $C_{\text {max }}$ : Maximum plasma concentration; EMA: European medicine agency; FDA: Food and drug administration; IV: Intravenous; Min: Minimum; Max: Maximum; OD: Once daily; PBPK: Physiological Based Pharmacokinetic model; $T_{\max }$ : Time to reach a maximum plasma concentration}

\section{Acknowledgements}

The authors are thankful to Bayer Technology Services, Leverkusen, Germany for providing an academic license of the Pk-Sim for this study. We are also thankful to Andrea Edginton, Associate professor, School of Pharmacy, University of Waterloo, Ontario, Canada for technical input and editorial help in compiling this manuscript. We acknowledge the input given by the reviewers till the final acceptance of this manuscript.

\section{Authors' contributions}

'MR' conceived the idea, implemented the research plan and carried out the experiments, computations and simulation on PK-Sim and wrote the manuscript of the findings. 'NIB' conceived the original idea of this study, designed and planned the work, presented the idea, provided the direction on work, and supervised the work and findings of the study. 'AH' and 'NA' were involved in planning, helped supervise the study and helped shape the manuscript with support from all authors. 'MWS' and 'MS' verified the procedures involved in the study, assisted in methodology, helped interpretation of the findings and given input on write up of the manuscript. 'FR' assisted in methodology, contributed to interpretation of the results, fine-tuned the findings of the product and contributed to the final version of the manuscript. 'MA' provided the technical input in simulation and helped to refine the manuscript. All authors provided critical feedback, discussed the results and contributed to the final manuscript. The author(s) read and approved the final manuscript. 


\section{Funding}

No author received any funding to carry out this project.

\section{Availability of data and materials}

All the data analyzed or generated during this study is given in manuscript. Extra information can be obtained from corresponding author, if needed.

\section{Ethics approval and consent to participate}

Not applicable' for that section.

\section{Consent for publication}

Not applicable for this section.

\section{Competing interests}

None of the authors has any competing interest.

\section{Author details}

'Punjab University College of Pharmacy, University of the Punjab, Lahore, Pakistan. ${ }^{2}$ Faculty of Pharmacy and Pharmaceutical Sciences, University of Alberta, Edmonton, Canada. ${ }^{3}$ College of Pharmacy, Al Ain University, Al Ain, Abu Dhabi, UAE. ${ }^{4}$ Clinical Pharmacology \& Quantitative Pharmacology, Clinical Pharmacology \& Safety Sciences, R\&D, AstraZeneca, Gothenburg, Sweden. ${ }^{5}$ Bahauddin Zakariya University, Multan, Pakistan.

Received: 19 November 2019 Accepted: 2 July 2020

Published online: 29 July 2020

\section{References}

1. Cella M, Knibbe C, Danhof M, Della Pasqua O. What is the right dose for children? Br J Clin Pharmacol. 2010;70:597-603.

2. Verbeeck RK, Musuamba FT. Pharmacokinetics and dosage adjustment in patients with renal dysfunction. Eur J Pharm Sci. 2009;65:757-73.

3. Verbeeck RK. Pharmacokinetics and dosage adjustment in patients with hepatic dysfunction. Eur J Pharm Sci. 2008;64:1147-61.

4. Lack J, Stuart-Taylor M. Calculation of drug dosage and body surface area of children. Br J Anaesth. 1997:78:601-5.

5. Barker Cl, Standing JF, Kelly LE, Faught LH, Needham AC, Rieder MJ, de Wildt SN, Offringa M. Pharmacokinetic studies in children: recommendations for practice and research. Arch Dis Child. 2018;103:695-702.

6. Maharaj AR, Edginton AN. Physiologically based pharmacokinetic modeling and simulation in pediatric drug development. CPT Pharmacometrics Syst Pharmacol. 2014;3:e150.

7. Sharma $V$, McNeill JH. To scale or not to scale: the principles of dose extrapolation. Br J Pharmacol. 2009;157:907-21.

8. Crawford JD, Terry ME, Rourke GM. Simplification of drug dosage calculation by application of the surface area principle. Pediatrics. 1950;5:783-90.

9. Anderson BJ, Meakin GH. Scaling for size: some implications for paediatric anaesthesia dosing. Pediatr Anesth. 2002;12:205-19.

10. Baker SD, Verweij J, Rowinsky EK, Donehower RC, Schellens JH, Grochow LB, Sparreboom A. Role of body surface area in dosing of investigational anticancer agents in adults, 1991-2001. J Natl Cancer Inst. 2002;94:1883-8.

11. Barrett JS. Della casa Alberighi O, Laer S, Meibohm B: physiologically based pharmacokinetic (PBPK) modeling in children. Clin Pharmacol Ther. 2012:92:40-9.

12. Macfarlane F: Paediatric anatomy and physiology and the basics of pediatric anasethesia. In Book Paediatric anatomy and physiology and the basics of pediatric anasethesia (Editor ed.^eds.). City: London: Anaesthesia UK; 2006.

13. Van Schoor J. Prescribing for children. Prof Nurs Today. 2006:10:26, 28-9.

14. Khalil F, Laer S. Physiologically based pharmacokinetic models in the prediction of oral drug exposure over the entire pediatric age range-sotalol as a model drug. AAPS J. 2014;16:226-39.

15. Bouzom F, Walther B. Pharmacokinetic predictions in children by using the physiologically based pharmacokinetic modelling. Fundam Clin Pharmacol. 2008;22:579-87.

16. Khalil F, Läer S. Physiologically based pharmacokinetic modeling: methodology, applications, and limitations with a focus on its role in pediatric drug development. J Biomed Biotechnol. 2011:2011:1-13.

17. Espié $P$, Tytgat D, Sargentini-Maier M-L, Poggesi I, Watelet J-B. Physiologically based pharmacokinetics (PBPK). Drug Metab Rev. 2009:41: 391-407.
18. Bouzom F, Ball K, Perdaems N, Walther B. Physiologically based pharmacokinetic (PBPK) modelling tools: how to fit with our needs? Biopharm Drug Dispos. 2012;33:55-71.

19. Delaney SR, Malik PR, Stefan C, Edginton AN, Colantonio DA, Ito S. Predicting escitalopram exposure to breastfeeding infants: integrating analytical and in silico techniques. Clin Pharmacokinet. 2018;57:1603-1611.

20. Stephens MM, Fox BA, Maxwell L. Therapeutic options for the treatment of hypertension in children and adolescents. Clin med insights, Circ Respir. 2012;6:13.

21. Raes A, Malfait F, Van Aken S, France A, Donckerwolcke R, Walle JV. Review: Lisinopril in paediatric medicine: a retrospective chart review of long-term treatment in children. J Renin-Angiotensin-Aldosterone Syst. 2007:8:3-12.

22. Chu PY, Campbell MJ, Miller SG, Hill KD. Anti-hypertensive drugs in children and adolescents. World J Cardiol. 2014;6:234

23. Soffer B, Zhang Z, Miller K, Vogt BA, Shahinfar S. A double-blind, placebocontrolled, dose-response study of the effectiveness and safety of lisinopril for children with hypertension. Am J Hypertens. 2003;16:795-800.

24. Trachtman H, Frymoyer A, Lewandowski A, Greenbaum LA, Feig DI, Gipson DS, Warady BA, Goebel JW, Schwartz GJ, Lewis K. Pharmacokinetics, pharmacodynamics, and safety of lisinopril in pediatric kidney transplant patients: implications for starting dose selection. Clin Pharmacol Ther. 2015;98:25-33.

25. Hogg RJ, Delucchi A, Sakihara G, Wells TG, Tenney F, Batisky DL, Blumer JL, Vogt BA, Lo M-W, Hand E. A multicenter study of the pharmacokinetics of lisinopril in pediatric patients with hypertension. Pediatr Nephrol. 2007;22: 695-701.

26. Tamimi J, Salem I, Alam SM, Zaman Q, Dham R. Bioequivalence evaluation of two brands of lisinopril tablets (Lisotec and Zestril) in healthy human volunteers. Biopharm Drug Dispos. 2005:26:335-9.

27. Brown J. Monohydrate lisinopril. In: Book monohydrate lisinopril (Editor ed. ^eds.). City: Google Patents; 2002.

28. Jagdale SC, Suryawanshi VM, Pandya SV, Kuchekar BS, Chabukswar AR. Development of press-coated, floating-pulsatile drug delivery of lisinopril. Sci Pharm. 2014;82:423.

29. Aditya G, Gudas GK, Bingi M, Debnath S, Rajesham V. Design and evaluation of controlled release mucoadhesive buccal tablets of lisinopril. Int J Curr Pharm Res. 2010;2:24-7.

30. Beermann B. Pharmacokinetics of lisinopril. Am J Med. 1988;85:25-30.

31. Lancaster SG, Todd PA. Lisinopril. Drugs. 1988:35:646-69.

32. Rioux N, Waters N. Physiologically based pharmacokinetic modeling in pediatric oncology drug development. Drug Metab Dispos. 2016:44:934-43.

33. Hornik C, Wu H, Edginton A, Watt K, Cohen-Wolkowiez M, Gonzalez D. Development of a pediatric physiologically-based pharmacokinetic model of clindamycin using opportunistic pharmacokinetic data. Clin Pharmacokinet. 2017;56:1343-53.

34. Eissing T, Kuepfer L, Becker C, Block M, Coboeken K, Gaub T, Goerlitz L, Jaeger J, Loosen R, Ludewig B. A computational systems biology software platform for multiscale modeling and simulation: integrating whole-body physiology, disease biology, and molecular reaction networks. Front Physiol. 2011:2:4.

35. Willmann S, Becker C, Burghaus R, Coboeken K, Edginton A, Lippert J, Siegmund HU, Thelen K, Muck W. Development of a paediatric populationbased model of the pharmacokinetics of rivaroxaban. Clin Pharmacokinet. 2014:53:89-102.

36. Remko M. Acidity, lipophilicity, solubility, absorption, and polar surface area of some ACE inhibitors. Chem Pap. 2007:61:133-41.

37. Gomez HJ, Cirillo VJ, Moncloa F. The clinical pharmacology of lisinopril. J Cardiovasc Pharmacol. 1987:9:S27-34

38. Lipinski CA, Lombardo F, Dominy BW, Feeney PJ. Experimental and computational approaches to estimate solubility and permeability in drug discovery and development settings. Adv Drug Deliv Rev. 1997;23:3-25.

39. Lisinopril. http://pubchem.ncbi.nlm.nih.gov/compound/lisinopril\#section= Solubility. Accessed 4 Aug 2019.

40. Gautam P, Vargas E, Lye M. Pharmacokinetics of lisinopril (MK521) in healthy young and elderly subjects and in elderly patients with cardiac failure. J Pharm Pharmacol. 1987;39:929-31.

41. Beermann B, Till AE, Gomez HJ, Hichens M, Bolognese JA, Junggren IL. Pharmacokinetics of lisinopril (IV/PO) in healthy volunteers. Biopharm Drug Dispos. 1989:10:397-409.

42. Mojaverian P, Rocci M, Vlasses P, Hoholick C, Clementi R, Ferguson R. Effect of food on the bioavailability of lisinopril, a nonsulfhydryl angiotensinconverting enzyme inhibitor. J Pharm Sci. 1986;75:395-7. 
43. Freeman HJ. Clinical relevance of intestinal peptide uptake. World J Gastrointest Pharmacol Ther. 2015;6:22.

44. The United States Pharmacopeia (USP 30), Lisinopril tablets. 2007;2:24832484

45. Siwale RC, Shabnam NS. Multiple-dosage regimens. In: Shargel L, ABC Y, editors. Applied Biopharmaceutics \& Pharmacokinetics. 7th ed. New York: McGra Hill Education; 2016.

46. Heilbron DC, Holliday MA, Al-Dahwi A, Kogan BA. Expressing glomerular filtration rate in children. Pediatr Nephrol. 1991;5:5-11.

47. Fernandez E, Perez R, Hernandez A, Tejada P, Arteta M, Ramos J. Factors and mechanisms for pharmacokinetic differences between pediatric population and adults. Pharmaceutics. 2011;3:53-72.

48. Cameron C, Vavilis G, Kowalski J, Tydén G, Berg UB, Krmar RT. An observational cohort study of the effect of hypertension on the loss of renal function in pediatric kidney recipients. Am J Hypertens. 2013;27:579-85.

49. Lombardo F, Berellini G, Obach R. Trend analysis of a database of intravenous pharmacokinetic parameters in humans for 1352 drug compounds. Drug Metab Dispos. 2018;46:1466-77.

50. Rasool MF, Khalil F, Läer S. A physiologically based pharmacokinetic drugdisease model to predict carvedilol exposure in adult and Paediatric heart failure patients by incorporating pathophysiological changes in hepatic and renal blood flows. Clin Pharmacokinet. 2015:54:943-62.

51. Van Schaik B, Geyskes G, Van der Wouw P, Van Rooij H, Porsius A. Pharmacokinetics of lisinopril in hypertensive patients with normal and impaired renal function. Eur J Clin Pharmacol. 1988;34:61-5.

52. Leary A, Dowling M, Wilson A, McKenna B, Rothwell J. A single-dose, randomised, crossover study to compare the rate and extent of absorption of lisinopril solution versus tablets in healthy volunteers. Paediatr Perinat Drug Ther. 2006;7:178.

53. Shaw W, Hogg R, Delucchi A, Sakihara G, Wells T, Tenney F, Batisky D, Blumer J, Vogt B, Murphy G. P-37: Lisinopril (L) pharmacokinetics (PK) in hypertensive children and infants. Am J Hypertens. 2002;15:46A.

54. Rhodin MM, Anderson BJ, Peters AM, Coulthard MG, Wilkins B, Cole M, Chatelut E, Grubb A, Veal GJ, Keir MJ. Human renal function maturation: a quantitative description using weight and postmenstrual age. Pediatr Nephrol. 2009;24:67.

\section{Publisher's Note}

Springer Nature remains neutral with regard to jurisdictional claims in published maps and institutional affiliations.

Ready to submit your research? Choose BMC and benefit from:

- fast, convenient online submission

- thorough peer review by experienced researchers in your field

- rapid publication on acceptance

- support for research data, including large and complex data types

- gold Open Access which fosters wider collaboration and increased citations

- maximum visibility for your research: over $100 \mathrm{M}$ website views per year

At BMC, research is always in progress.

Learn more biomedcentral.com/submissions 